ISSN 1014-4874

DOI : http://dx.doi.org/10.4314/rj.v26i1.2

\title{
Trade, Standards and Vertical Coordination: Evidence from The Rwandan Coffee Sector.
}

\author{
Jean Chrysostome Ngabitsinze
}

\begin{abstract}
This paper explores the impact on small farmers of several recent investments in the Rwandan coffee supply chain. The purpose of the investments was to modernize the coffee value chain and to promote the production of speciality coffee. A research team surveyed 254 small farmers and 16 washing stations to measure the level of participation of farmers in the modern speciality coffee supply chain and with exporters companies. We found that farmers participating in the speciality coffee value chain received a higher price for their coffee beans compared to those who produce in the value chain of standard quality. Additionally, we demonstrated that farmers' membership of a cooperative positively affected the probability of his/her participation in the speciality coffee value chain. Contrary to other studies, no a significant effect of other farm and household characteristics on the farmers' involvement in the modern supply chain.
\end{abstract}

Keywords: Rwanda, Trade Liberalization, FDI, vertical coordination, Standards, Speciality coffee, modern supply chain.

\section{Introduction}

Rwanda is a small land-locked country with a population of 9, 3 millions, in 2007 , and density ( 368 persons per $\mathrm{Km}^{2}$ ). The structure of population shows that $16,3 \%$ are under 5 years old, $41.9 \%$ are under 15 years old and $55.5 \%$ years are between $15-64$ years old, with $2,6 \%$ of population over 65 years old ${ }^{1}$. The GDP at current 2007 prices is estimated at $1,838.9$ billions RwF. (Rwanda Franc), with an estimated per capita GDP of 197.731 RwF or $\$ 360$. Reference should be inserted here

Coffee in Rwanda dates from its introduction in 1904 with its first export occurring in 1917. It was imposed by the colonialists to the agriculturists since 1927 and after the independence, the cultivation of coffee continued to benefit from the support of the authorities. Upon its introduction, coffee became the major source of income in rural Rwanda and benefited from

\footnotetext{
${ }^{1}$ This general information come from National Institute of Statistics of Rwanda, Quarterly Economic Review/ January to march 2008
} 
strong political support from colonial and post-colonial authorities. Its cultivation was made compulsory in 1933 and legislation passed at Independence in 1963 prohibits uprooting of coffee trees. Historically, the colonial authorities essentially forced farmers to grow coffee.

The Ministry of Agriculture and Animal resources (MINAGRI) established a parastatal agency, OCIR-Café with monopolistic powers to organize the smallholder planters, purchase their crops in the form of café parche contract with private factories the processing of the parche into green coffee (café marchand) and sell the final on the international market. Office Nationale des Cultures Industrielles (OCIR) was created in 1964 with a mandate of searching for marketing outlets for the coffee produced in Rwanda. Tea production had not yet begun and was included letter. At the time and up to 1988, two exporting companies Rwandex and Etiru had marketing monopolies. By far, Rwandex had the greater share of the exports. Some sort of reference for the source of information.

Market research was commenced in 1991 to introduce liberalization, which started only after 1994 genocide with the licensing of several private coffee exporters and the installation of several parchment mills by companies Rwandex, Rwacof, Coffex, and Caferwa, thus the coffee marketing chain has now changed from the central monopsony to a free market. The mandate of OCIR-Café has changed and now is promotion regulation and monitoring agency in the sub-sector. Private traders are now allowed to purchase parchment coffee from the small holders growers and to sell it to the hulling companies. Export is increasingly carried out by private enterprises. The coffee export earnings amounted to only 20 million USD in 2001 against 60 million USD in 1990.(Ocir café, annual report, 2001)

In his study, Loveridge (2003) found that the decline in coffee production was primarily due to reduced numbers of growers and production was more geographically concentrated than in pre-war years. A diagnostic analysis of the Rwandan coffee supply chain carried out by a coffee expert on the account of SNV (the Netherlands development organization, 2007) mentioned three main reasons of that decrease next to the decreasing of world coffee prices: the old age of the coffee-trees (a large number of trees exceed 20-25 years, the limiting age of an economically optimal exploitation); the low remunerative price of green coffee which encourages the growers to divert towards the cultivation of food crops; the abandonment of good cultivation methods (cut backs, pruning, mulching, etc). In response to the steady decline in production, quality and export earnings, and in view of the recognized potential contribution that the sector could make to increase economic growth, the government of Rwanda adopted the 1999-2003 Coffee and Action Plan. In 2004, an exploratory 
study carried out by the American consultancy firm On the Frontier (OTC), assisted the Government of Rwanda in redefining policies and strategies according to the previous 1999-2003 action plan and set the "Horizon 2010 Coffee Action Plan".

The Coffee Washing Stations, Speciality Coffee, Commercialization and Export activities: The coffee Washing Station are units specialized in depulping, washing and drying cherries, in order to obtain high quality of coffee (fully washed coffee). After harvest farmers sell their cherries to Washing Station (WS) or they process cherries using pulping center located in rural areas or they do process themselves at home using indigenous equipments. Using this method they obtain not fully washed coffee but a semi washed coffee. After depulping activity farmers wash the product and then proceed to the drying of coffee, normally they stop when the coffee has $15-18 \%$ humidity. Buyers intervene at the collection of parchment coffee by purchasing to farmers and then sell to exporters. In general these buyers receive commission from exporters on which they depend to pay farmers.

Fully washed coffee is transformed in CWS, but the production still insignificant, it represents approximately $10-12 \%$ (OCIR-Café, annual report 2008). Activity starts at farm level where farmers after harvesting, cherries are either transported to coffee washing stations by these farmers or the WS organize collection point (for to minimize transportation costs) in their working environment based on coffee plantations in the area. This modern technology consists of mechanically de-pulping and washes the fresh cherries in coffee washing stations which are located within walking distance of the coffee producing farms, so that delivery occurs within a few hours after harvesting. This process includes a first screening of the fresh cherries, rejecting those of sub-standard quality. After de-pulping and the washing, the products are stored in WS warehouse before their transportation to be parched. The WS pay the transportation fees. Is very important to note that cooperatives or privates owning CWS, will pay services provided by exporters (parchment, storage, exportation commission).

Exporting factories receive semi-washed coffee from the buyers and coffee from CWS which will be fully washed coffee but these product are separately stored. These coffees are subject to a second screen for quality certificate using standards for Speciality Coffee Association of America (SCAA) and the mechanically hulled (de-parched). The product of this process is green coffee which is the final product Rwanda exports. Each deparched lot is transported to OCIR-Café where analysis are carried out in 
order to deliver quality certificate, exportation licence of the lot and certificat d'origine. The Ministry of Agriculture delivers the Phytosanitary certificate and then the lot can be exported via Mombasa or Dar- es Salam. Lots are made 300 bags $(60 \mathrm{kgs})$ making a normal quantity within a container of 18 tons.

Regarding other findings in vertical coordination studies, several studies indicated that foreign firms facilitate the adoption of new technology and can solve contract enforcement problems (Key and Runsten 2009 ; Gow and Swinnen 1998). However most studies concluded that the impact on local supplies is mostly negative, in particular for small suppliers in developing countries (Dolan and Humphrey 2000; Weatherspoon and Reardon 2002). The latter often cannot comply with the higher standards and grading requirements for the supplied products (Farina and Reardon, 2000; Henson et al., 2000; Reardon at al., 1999). Moreover, foreign investors prefer to deal with a few large suppliers to minimize transaction costs, forcing consolidation of the supplier base and hence separating many small suppliers from their traditional outlets (Runsten and Key 2000; Holloway et al., 2000; Winters 2000).

In most developing countries and transition countries, farms vary widely in size and organization, from small household plots, over family farms, to large cooperatives or farming companies. For example, in Slovakia, almost all land is used by large farming corporations, whereas in countries such as Albania, Azerbaijan and most countries in Africa and Asia, almost all land is used by small individual farms Miet and Swinnen, 2008).

In studying vertical coordination for those countries many authors have found that this process can exclude a large share of farmers, and in particular smaller ones (Miet and Swinnen, 2008). Thus our research provides new evidence on the actual situation of Rwanda coffee sector after several transformation as a need to produce speciality coffee. The main purpose of the paper is to analyse the effectiveness of the co-ordination mechanism from the importance of contracting practice and to explain the latent dimensions of contracting motivation.

Actual literature on vertical coordination (VC) distinguished two extreme co-ordination mechanisms: spot market "external co-ordination" and vertical integration "internal co-ordination" (Szabò and Bàrdos, 2005, Maertens and Swinnen, 2006). For Boland et al. (2002) vertical coordination is an important part of competitive strategy, they define it as "various methods used to manage vertical stages in a marketing channel". For Drescher (2002) vertical coordination is "the general term that includes all ways of harmonizing the vertical stages of production and marketing". 
Vertical coordination may occur at various stages in a supply chain. Two common examples are between a processor and a farm from which the processor purchases products, or between a farm and an input supply company (Swinnen, 2005). The Economic Research Service Report of the United State Department of Agriculture (USDA ERS, 2004) stated that methods of vertical coordination change over time and vary across commodities. For example, today's fams are often more specialized, and less vertically integrated, than in the past.

\section{Materials and Methods}

The analysis of coffee supply chain in Rwanda was based on interviews at various level of the supply chain and a representative coffee growers surveyed First at processing and marketing level, several interviews were held with managers, technicians of the 16 washing stations as processing firms regarding their operation capacity, employment, investments, production input and output, quality of input and output, contract details downstream (with farmers), price policy towards farmers, contract details upstream (with purchasing firms of fully washed coffee), financial viability of the washing stations and quality testing and roasting within the washing station.

Second the supply coffee growers (76 coffee growers and 178 no coffee growers) survey was organized during the months of July and August 2008. All 254 households interviewed in July and August 2008 are part of a panel set. Three time observations were made, the first spanning the crop season from October 1989 through March 1990, the second spanning the same crop season 12 years later, from October 2001 through March 2002 (Marijke, 2002). The 1990 data come from a national farm survey carried out by the division of Agricultural Statistics (DSA) of Rwanda's Ministry of Agriculture and Livestock (MINAGRI). This survey was based on national random sample of approximately 1,248 farm households. The survey was geographically stratified in clusters of 16 households. It provided data on output, area and yields and information on topics such as livestock, non-farm income, household composition and schooling. The data on economic activities in 2002 were collected in the February and March as a part of a study for Belgian Department for Development Cooperation (DGOS) under the Policy Research Program. The survey conducted in 2002 covered 212 out of the 256 households in the 1990 survey in two provinces Gikongoro and Gitarama. The survey conducted in 2008 covered 254 of 256 households surveyed in 2002. The households were located in 16 different clusters in the two provinces. In 2008 survey, some questions were added for capturing the coffee growers characteristics between 2002 and 2008 . 


\section{Results and Discussion}

\subsection{Small coffees farmers characteristics and determinants of participation in specialty Coffee.}

The results from the survey showed that coffee growers were 229 in 2002. Coffee growers $(6.3 \%)$ indicated that the decision to not grow coffee, was due to poor soils whereas $1.2 \%$ confirmed that the land was not enough. The and almost $0.4 \%$ they responded didn't know the motivation. Comparing to 2008 survey results, the number of coffee growers decreased to 89 coffee growers (Table 1). Coffee growers (23.4\%) confirmed that they stopped to grow coffee because the climate is not favourable whereas $20.1 \%$ stated that the land was not sufficient to as they had to cultivate other food crop. (Table1). No problem about diseases of coffee and number of coffee Washing stations were noted. The big problem identified was the size of land and climate conditions.

Table 1: Sample Characteristics of coffee growers

\begin{tabular}{lcccc}
\hline \multicolumn{4}{c}{$\mathbf{2 0 0 2}$} & \multicolumn{2}{c}{$\mathbf{2 0 0 8}$} & \\
\hline Variable & $\boldsymbol{N}$ & Valid percentage & $\boldsymbol{N}$ & Valid percentage \\
\hline Coffee growers ? & & & & \\
Yes & 229 & 90.2 & 89 & 35.2 \\
Not & 23 & 9.1 & 156 & 61.7 \\
Missing & 2 & 0.8 & 9 & 3.1 \\
Total & $\mathbf{2 5 4}$ & $\mathbf{1 0 0}$ & $\mathbf{2 5 4}$ & $\mathbf{1 0 0}$ \\
If not why? & & & & \\
The soil is not good? & 16 & 6.3 & 60 & 23.4 \\
Not enough land & 3 & 1.2 & 51 & 20.1 \\
Do not know & 4 & 1.6 & 5 & 2 \\
Other & 1 & 0.4 & 34 & 13.6 \\
Missing & 230 & 90.6 & 104 & 40.9 \\
\hline Total & $\mathbf{2 5 4}$ & $\mathbf{1 0 0}$ & $\mathbf{2 5 4}$ & $\mathbf{1 0 0}$ \\
\hline Source: Own Data, $\mathbf{2 0 0 8}$ & & & &
\end{tabular}

Source: Own Data, 2008

Farms size in Rwanda are small, even for the relatively large landowners: the median area owned per households is estimated at about 0.5 ha based on national household survey (EICV II, 2005-06). In this survey, the total area cultivated was estimated to a maximum of 0 ,48ha (Table 2). Household members $(44.7 \%)$ were males while $55.3 \%$ were females. The higher number of female in the households is the negative result of 
genocide in 1994, during this period several males have been killed. The education level of households was dominated by primary level. The share of primary level was $63.2 \%$, post primary (the professional schools) $9.2 \%$, high school 3.9\% and $23.7 \%$ did not have any education (Table 2). The mean number of tree was 195.94 per households. The mean number of trees in Rwanda coffee sector was reported to vary between 150 and 200 trees per households. (Ocir Café survey 1999).

Table 2: Descriptive statistics of coffee growers characteristics

\begin{tabular}{|l|l|l|l|l|l|r|r|}
\hline \multicolumn{1}{|c|}{ Variables } & Unit & \% & N & $\begin{array}{c}\text { Mea } \\
\boldsymbol{n}\end{array}$ & $\begin{array}{c}\text { Std.D } \\
\text { ev }\end{array}$ & Min & Max \\
\hline $\begin{array}{l}\text { Participation of hhs } \\
\text { members }\end{array}$ & No & & 76 & 3.94 & 7.18 & 2,00 & 5 \\
\hline $\begin{array}{l}\text { Participation of non hhs } \\
\text { members }\end{array}$ & No & & 76 & 1.07 & 1.5 & 0,00 & 8 \\
\hline Coffee area & $\mathrm{m}^{2}$ & & 76 & $\begin{array}{c}127.6 \\
210.8\end{array}$ & 5 & & 4800 \\
\hline Number of coffee trees & No & & 76 & $\begin{array}{c}195.9 \\
201.7\end{array}$ & 5 & 0,00 & 1200 \\
\hline Education of hhs head & & & & & & & \\
\hline Primary & $\%$ & 63.2 & 48 & & & & \\
\hline Post primary & $\%$ & 9.2 & 7 & & & & \\
\hline High school & $\%$ & 3.9 & 3 & & & & \\
\hline None & $\%$ & 23.7 & 18 & & & & \\
\hline $\begin{array}{l}\text { Number of trees in } \\
\text { production }\end{array}$ & No & & & 195.9 & 201.7 & & \\
\hline Sex of head households & & & & & & & \\
\hline M & $\%$ & 44.7 & 34 & & & & \\
\hline F & $\%$ & 55.3 & 42 & & & & \\
\hline Types of trees & & & & & & & \\
\hline Robusta & $\%$ & 6.25 & 75 & & & & \\
\hline Others & $\%$ & 8.33 & 100 & & & & \\
\hline & & & 102 & & & & \\
\hline Arabica & & 85.42 & 5 & & & & \\
\hline $\begin{array}{l}\text { Labor use and inputs } \\
\text { use }\end{array}$ & & & & & & & \\
\hline Prune the trees & Freq & & & 0.65 & 1.60 & 0.00 & 14 \\
\hline Égourmandage & Freq & & & 1.38 & 3.14 & 0,00 & 22 \\
\hline
\end{tabular}




\begin{tabular}{|l|l|l|l|l|l|l|l|}
\hline Mettre de paillis & freq & & & 1.88 & 2.40 & 0,00 & 20 \\
\hline Déserber & freq & & & 2.18 & 5.25 & 0,00 & 45 \\
\hline Mulching & freq & & & 1.78 & 3.45 & 0,00 & 41 \\
\hline $\begin{array}{l}\text { Phytosanitary products } \\
\text { use }\end{array}$ & freq & & & 0.56 & 0.92 & 0,00 & 6 \\
\hline $\begin{array}{l}\text { Quantity of "Célises" } \\
\text { harvested }\end{array}$ & $\mathrm{Kg}$ & & & $\begin{array}{c}565.1 \\
4\end{array}$ & $\begin{array}{c}1182 . \\
75\end{array}$ & 0,00 & 8010 \\
\hline
\end{tabular}

*Frequency during the year. hh: household, M: male, F: female

Source: own survey, 2008

According to several studies, participation in speciality market involves the adoption of quality standards and specific production techniques. To identify indicators for inclusion in this study and their respective hypothesis, the literature on adoption of innovations and program participation was examined. Several studies have indicated that education (De souza Filho, Cyphers et al 1993; Henning 1994), land size (Chambers and Foster 1983; Zbinden and Lee 2005), membership in farms' organization (De souza Filho, Yound et al., 1999), access to extension services (Nowak 1987) and household labour availability (Neupane, Sharma at al. 2002; Zbinden and Lee 2005) influence the adoption of innovative agricultural practices. Education was reported to increase farmers' ability to process information and to implement new production standards (Zbinden and Lee 2005) and thus to increase the probability of participation in speciality markets. Similarly, experience in coffee cultivation is positively associated with participation in speciality channels. Moreover it is expected that size of the coffee plantation to have a positive impact on participation. Furthermore, the adoption of labour intensive quality standards and sustainable production techniques may be constraint by limited availability of family labour.

In this survey, the level of education level did not influence the families to sell or not sell their coffee (cherries and parche) to the Station Washing. This conclusion was arrived at after running a Anova tests using the coffee sold to the Washing stations (1) and Local buyer (2) as dependent variables and the level of education and sex of the head of households as independent variables. In coffee sector in Rwanda, the level of education and sex of household had not effect for the choice marketing channel. This implies that the small coffee growers are indifferent to selling the coffee cherries to a Station Washing or to Local buyer (Table 3 and 4). This explains why today in Rwanda the fully washed coffee is very low in quantity than semiwashed coffee. The unique variable that can show the decision on 
participation in speciality markets was not surprising the land size. Several cooperatives were founded by farmers with a big size of land and many coffee trees.

Table 3: ANOVA results comparing the channel of marketing with coffee cherries as dependent variable

\begin{tabular}{lccccc}
\hline & Sum of Squares & $\boldsymbol{d} \boldsymbol{f}$ & Mean Square & $\boldsymbol{F}$ & Sig. \\
\hline Between Groups & 0.966 & 1 & 0.966 & 0.583 & 0.452 \\
Within Groups & 43.076 & 26 & 1.657 & & \\
Total & 44.04 & 27 & & & \\
Between Groups & 20.09 & 1 & 20.09 & 23.48 & 0.000 \\
Within Group & 23.14 & 26 & 0.890 & & \\
Total & 44.04 & 27 & & & \\
\hline
\end{tabular}

We use coffee cherries sold to washing stations and local buyers as dependents variables.

We use sex as a first group independent variable and level of instruction second group as independent variable

Source: own survey, 2008

Table 4: ANOVA results comparing the channel of marketing with coffee parched as dependent variable

\begin{tabular}{lccccc}
\hline & Sum of Squares & $\boldsymbol{d f}$ & Mean Square & $\boldsymbol{F}$ & Sig. \\
\hline Between Groups & 0.962 & 2 & 0.481 & 0.191 & 0.824 \\
Within Groups & 116.57 & 47 & 2.48 & & \\
Total & 117.53 & 49 & & & \\
Between Groups & 0.091 & 1 & 0.09 & 23.48 & 0.000 \\
Within Group & 117.44 & 48 & 2.44 & & \\
Total & 117.53 & 49 & & & \\
\hline
\end{tabular}

We use coffee parched sold to washing stations and local buyers as dependents variables.

We use sex as a first group independent variable and level instruction second group as independent variable.

Source: own survey, 2008

use a Simple linear regression model was used to explain the total quantity of cherries produced, on the basis of the following determinants: level of education, sex of household, number of coffee trees and total area cultivated. The results showed that the unique variable statistically 
significant in the model was the number of coffee trees (Table 5). As expected, there are a positive correlation between total quantity produced and total area cultivated.

Table 5: Determinant of coffee cherries production: OLS regression

\begin{tabular}{lccc}
\hline Parameter & Coefficients & t-statistics & p-value \\
\hline Intercept & -2.247 & -1.624 & 0.112 \\
Sex(male) & -0.135 & -0.28 & 0.781 \\
Without primary school & 0.370 & 0.650 & 0.520 \\
Primary school & 1.118 & 1.365 & 0.180 \\
Post primary school & -0.282 & -0.183 & 0.856 \\
Age & 0.013 & 1.047 & 0.301 \\
log total area & 0.134 & 0.682 & 0.499 \\
log number coffee trees & 1.189 & 4.353 & 0.00 \\
\hline
\end{tabular}

R Squared $=0.454$

Source: own survey, 2008

Analyzing data on washing stations contract with small farmers, it was noted that washing stations don't offer enough physical inputs to farmers'. Only $20.9 \%$ offer credits to small farmers', $23.9 \%$ give chemical fertilizer, $22.2 \%$ give pesticides, insecticides, herbicides and only 22.4 give seeds to small farmers. Results in Table 6 regarding the provision of other services and inputs offer such as extension service, transportation arrangement and insurance in case of harvest failure, it was observed that the washing stations don't offer enough assistance.

On the other hand, the situation of supply chain in coffee sector in Rwanda at first level of the channel (small growers and washing stations) presents several anomalies. It was found that the level of education of growers and sex of household head was not statistically significant and did not have a positive effect on participation in supply chain as the way to produce speciality coffee. Without using the Phytosanitary products and other modern methods, the small farmers continue to have a positive quantity and income but the quality is so low. Meike and Manfred (2006), studying coffee speciality marketing in Costa Rica found that education and land size had a significant and positive effect on participation in speciality marketing. 
Table: 6: Contract downstream between Washing Station and Farmers

\begin{tabular}{lcc}
\hline $\begin{array}{l}\text { Does Washing Station offer the following } \\
\text { services? }\end{array}$ & $\begin{array}{c}\text { Valid } \\
\text { percent }\end{array}$ & $\begin{array}{c}\text { Cumulative } \\
\text { percent }\end{array}$ \\
\hline Yes & 78 & 78 \\
Not & 22 & 100 \\
Total & 23.3 & 23,3 \\
Credit & 26.7 & 50 \\
Chemical fertilizer & 25 & 75 \\
Pesticides, Insecticides, Herbicides & 25 & 100 \\
Seedlings & & \\
\hline What was the effect of the introduction on & & \\
the quantity? & 42.2 & 42.2 \\
1. Very positive & 46.7 & 88.9 \\
2. Rather positive & 11.4 & 97.7 \\
3. No effect & 2.3 & 100 \\
5. Very negative & & \\
What was the effect of the introduction on & & \\
the quality? & 42.2 & 42.2 \\
1. Very positive & 46.7 & 88.9 \\
2. Rather positive & 8.9 & 97.8 \\
3. No effect & 2.2 & 100 \\
5. Very negative & & \\
\hline How common are the following problems? & & \\
Coffee Leave Rust (CLR) & 21.4 & 21.4 \\
Very common & 35.7 & 57.1 \\
Rather common & 42.9 & 100 \\
Rather not common & & \\
Coffee Berry Disease (CBD) & 21.4 & 21.4 \\
Very common & 35.7 & 57.1 \\
Rather common & 42,9 & 100 \\
Rather not common & 29.4 & 29.4 \\
Bacterial Blight of Coffee (BBC) & 47.1 & 76.5 \\
Very common & 23.5 & 100 \\
Rather common & \\
Rather not common & & \\
\hline
\end{tabular}




\begin{tabular}{|c|c|c|}
\hline \multicolumn{3}{|l|}{$\begin{array}{l}\text { Other services and input } \\
\text { Does the washing station offer the } \\
\text { following service to farmers? }\end{array}$} \\
\hline YES & 41.7 & 41.7 \\
\hline NOT & 58.3 & 100 \\
\hline Extension service & 21.0 & 21.0 \\
\hline Transportation & 22.6 & 43.5 \\
\hline Specialized storage & 19.4 & 62.9 \\
\hline Insurance (in case of harvest failure & 21.0 & 83.9 \\
\hline $\begin{array}{l}\text { Farm loan guarantees (given by processor to } \\
\text { bank) }\end{array}$ & 16.1 & 100 \\
\hline
\end{tabular}

Source: own survey, 2008

\subsection{Washing Stations, Trade, Standards and incomes}

\section{Washing stations}

Washing station (W.S) were founded by cooperatives or private sector. They are units specialized in depulping, washing and drying cherries, in order to obtain high quality of coffee, (fully washed coffee). Washing stations enforce quality control from the moment coffee arrives from the field as cherries (the bean itself the seed of the fruit of the coffee plant). Farmers are paid on pure weight of quality cherries while substandard cherries and detritus are discarded. By significant raising the quality of Rwandan coffee, the international coffee market rewards producers by paying from 3 to 5 times the price per pound of superior product. In many areas farmers grouped in cooperatives set up coffee washing stations, so they can improve quality by producing fully washed coffee. The small farmers who are not cooperatives members sell their coffee to a private or to local buyer nor to a cooperative. Several small farmers as shown before, prefers to carry out primary processing using the wet process method. In Rwanda dry processing of coffee is prohibited.

The process of producing speciality coffee appears to involve a combination of improvement at farm level and washing/processing quality and better marketing, especially direct marketing to importers where trust can be established ${ }^{2}$

\footnotetext{
${ }^{2}$ The Government of Rwanda adopted a "1999-2003 Coffee Strategy and Action Plan" that focused on increasing production through use of improved coffee varieties and improving husbandry, improving quality through producer education and investment in washing stations, and promoting equity in value distribution by increasing producer participation in marketing. This plan was supplemented with a
} 
According to the work of Karol Boudreaux (2006), at cooperatives level across the country, Rwandans small farmers are connecting their efforts with the worldwide market for speciality coffee. In order to capture more of this market. However, as shown before, the problem is that several small farmers are not into a cooperative system. To be part of a cooperative is important learn how to care for coffee trees, how best to store and transport beans, how to cup coffee and how to market it.

Interviewing the Washing Stations managers on their perception of coffee growers treatments, it was noted that several of them consider that the way of planting, the frequency of weeding, the way and frequency of mulching, the way and timing of pruning, fertilizer use, use of Phytosanitary and timing of transportation are very important for coffee quality coffee production (Table 7). The principle problem identified was that the cooperatives don't offer those assistance to small growers in which they are not members.

Table 7: Washing stations managers perception of coffee growing treatment

\begin{tabular}{|c|c|c|}
\hline $\begin{array}{l}\text { How important are the } \\
\text { following production } \\
\text { inputs and techniques in } \\
\text { determining: }\end{array}$ & Valid percent & Cumulative percent \\
\hline \multicolumn{3}{|l|}{ The way of planting } \\
\hline Very important & 75 & 75 \\
\hline Rather important & 25 & 100 \\
\hline \multicolumn{3}{|l|}{ The frequency of weeding } \\
\hline Very important & 70.6 & 70.6 \\
\hline Rather important & 29.4 & 100 \\
\hline \multicolumn{3}{|l|}{$\begin{array}{l}\text { The way and frequency of } \\
\text { mulching }\end{array}$} \\
\hline Very important & 82.4 & 82.4 \\
\hline $\begin{array}{l}\text { Rather important } \\
\text { The way and timing of } \\
\text { pruning }\end{array}$ & 17.6 & 100 \\
\hline Very important & 58.2 & 58.2 \\
\hline rather important & 41.2 & 100 \\
\hline
\end{tabular}

"Horizon 2010 Coffee Action Plan" that calls for investing nearly \$60 million during the period 2005-2010 to develop and support the quality coffee sector. 
Fertilizer use

Very important

Rather important

Use of Phyto-sanitary

products

Very important

Rather important

Timing of transportation

Very important

Rather important

Rather not important

Not important at all
70.6

29.4

70.6

100

70.6

29.4

70.6

100

37.5

37.5

$\begin{array}{ll}37.5 & 81.3\end{array}$

6.3
6.3

$6.3 \quad 93.6$

Number of Observation: 16 Washing Stations

Source: own survey, 2008

\section{Trade and standard}

Coffee is one of the first internationally traded products where collective efforts were undertaken to develop standards on process that address socioeconomic and environmental concerns. Some coffee like the organic, Fair trade, Bird Friendly, Rainforest Alliance and Utz Kapeh are sold as certified coffee $^{3}$. Others are sold under sustainability initiatives that are designated by private enterprises with or without third-party monitoring. In

\footnotetext{
${ }^{3}$ Organic coffee certification is based on a production management system that aims at promoting and ehancing natural soil activity and prohibits synthetically produced agroecomicals. It is based on minimal use off-farm inputs and on management practices that seeks to restore, maintain and enhance ecological harmony. Accredited certification agencies monitor organic standards on production, processing and handling. In the last decade, its popularity in many major markets has brought this standards into the realm of public regulation.

Fair trade is defined as a "an alternative approach to conventional trade that aims to improve the livelihoods and well being of small producers by improving, processing strengthening their organizations, paying them a fair price with a fixed minimum, and providing continuity in trading relationships"

Smithsonian Migration Bird Center's (SMBC) Bird Friendly coffee and the Rainforest Alliance-certified are the two labels that offer certifiable standards for eco-friendly or shade-grown coffee.

Utz Kapeh, originally set up by Ahold Coffee Company to serve its private needs, is now and independent foundation and has developed a certifiable code of conduct for growing sustainable coffee-primarily on the combined basis of the good agricultural practices of the European Retailer Group (EUREP-GAP) and the social guide lines outlines in SAI 8000. It provides a minimum assurance that basic conditions are met and is less rigorous that the previously mentioned certifications.
} 
Rwanda all most coffee quality are certified with organic certification methods and Fair trade certification.

Although there are fewer coffee producers, coffee remain Rwanda's major export crop and close to 500,000 families are involved in the coffee sector (Ocir café, 2008). Only Arabica coffee is grown in Rwanda, primarily Bourbon variety, a particularly good quality coffee. In interviews with small farmers some of them reported togrow also Robusta, but this information may be connected to small farmers lack of knowlwdge on which coffee varieties are growing. According to OCIR-Café and other ONG, Rwanda coffee is $100 \%$ Arabica.

Coffee exports represent more than 50 percent of Rwanda export income. In 2004 export was 32.4 millions of USD, with coffee production in tons 28,858 . Its contribution on Rwanda export was $29 \%$ and coffee revenue in rural areas was about 17 billions of RwF. In 2006, the situation improved sharply, with an export value of 54 millions of USD, and a coffee production of 26,291 tons. Thus the total export increase to $31 \%$, while the rural revenue increase to 23 billions of RwF. The amount of fully washed coffee also rose as the number of washing stations increased. By spring 2006, there were 46 washing stations in Rwanda.

However in 2000, there were only two Washing stations in the country (Nkora and Masaka, year) neither of which worked, actually there are now 120 operating Washing Stations. The government-controlled coffee agency OCIR-Café, notes "reflecting the push toward higher quality, the production of fully washed coffee rose to 1100 tons, an increase of 400 tons from 2004 indicate the reference here ${ }^{4}$.

In the past, Rwanda exported most its higher-grade coffee to Europe, little made its way to the United States. Today more Rwandan coffee is available in the United States. In fact U.S importers and roasters have expressed strong interest in the products and in supporting improvements in Rwanda coffee. USA importers are particularly interested in speciality Rwandan Coffee, coffee of high quality that meets the demands of sophisticated coffee drinkers.

\section{Income effect}

The speciality coffee industry in Rwanda, is now helping to change lives of the people. By growing better quality coffee, producers are earnings more. While low-grade coffee sells for approximately US\$ 2.1 per KG, speciality

\footnotetext{
${ }^{4}$ Café du Rwanda, rapport annuel 2005, OCIR-Café.
} 
coffee fetches US\$ 3.6per Kg. Explaining prices in an OLS regression with a dummy for coffee sold off season (January -June), with a very good fit: almost $70 \%$ of the variation in coffee prices can be explain by time of the year and type of coffee, with all coefficients highly significant and making very good sense ( $t$-statistics in parenthesis under coefficients).

$\begin{array}{rr}\text { Price } / \mathrm{Kg}=1.10-0.17 \mathrm{Q}_{\mathrm{low}}+1.05 \mathrm{Q}_{\text {stand }}+2.42 \mathrm{Q}_{\text {high }} \\ (-4.50) & (17.10)\end{array}$

Obs $=785$, R-Squared $=0.69$

Some importers are paying upwards of US\$ 6 per lot (OCIR Café, Cup of excellence, Kigali, 2008) per pound Rwandan speciality coffee.

A USAID report (2006) showed that approximately 50,000 households had their incomes from coffee production double and some 2,000 jobs created at coffee washing stations. According to this information, any Washing station had a maximum number of 9 managers with a mean of almost 4 managers and a maximum number of 11 technicians with a mean almost 4 . The number of labourers used during the year ranged from a minimum of 20 to a maximum of 500 employees.

Last year Rwanda was the first African country to host the international Cup of Excellence $(\mathrm{CoE})^{5}$ competition event. The event was honoured by participation of an elite group of 24 International Cuppers that was climaxed by the award of two presidential and 22 ordinary Cup of Excellence to be auctioned in internet from October 2008. The first winner (Buremera Mig- Uwimana Rose) cooperative awarded a high bid of $\$ 18.00 / 1$ lot size with a total value of $52,381.83$ for 22 lot size, the high bidder was Solberg\& Hansen As from USA.

\section{Conclusion}

Coffee in Rwanda like other major agricultural exports such as tea and sugar is mainly produced in commercial estates. These crops are capital intensive and require a lot fixed investments in the plantation and processing facilities. With respect to coffee, due to the perennial nature of crop, the opportunity costs of investing a perennial for smallholder farmers is high and they tend to be risk averse.

\footnotetext{
${ }^{5}$ A Cup of Excellence is a strict competition that selects the very best coffee produced in that country for that particular year. These winning coffee are chosen by a select group of national and international cuppers and are cupped at least five different times during the competition process. The final winners are awarded the prestigious Cup of Excellence and sold to the higher bidder during auction.
} 
The participation of smallholder farmers in coffee, tea and sugar was previously facilitated by state intervention through the creation of stateowned crop authorities with the responsibility of promoting the participation of smallholder farmers in the production of high value agricultural crops.

Then main evidence of this study shows that participation in speciality coffee marketing channels and participation in cooperatives both serve to increase prices received by producers. The study showed also that the level of incomes between small farmers, no cooperatives members was different to small farmers who participate in cooperatives system. To be a member of cooperative increase the possibility to produce high quality of coffee cherries and to receive a good level of price, but to become a member of those cooperatives, small farmers need to have many coffee trees and a good level of education.

This study revealed that reforms in smallholder coffee sector were more farmer-centred, by focusing on building the capacity of smallholder farmers to run their own operations. The government of Rwanda could do even more to support the small farmers who are not involved in cooperatives and associations system. The just way is to promote the training system to show them that produce coffee quality is also important for them, because when you discuss with small farmers that not participate in any cooperatives, they think that the government don't give them any importance. The government can assist them giving the phytosanitary products, transportation assistance, and control seriously the use of hytosanitary products.

About credit support: subsidized credit might be needed to finance the initial investments necessary for setting up different production and some modest scheme to support the individual producer's income temporarily during the unproductive phase.

\section{References}

1. Bacon, C., 2005. Confronting the coffee crisis: can fair trade, organic and speciality coffees reduce small-scale farmer vulnerability in northern Nicaragua? World Development, 33 (3), 491-511.

2. Blackman, A., Alberts, H., Avalos-Sartorio, B. and Crooks, L., 2005. Deforestation and shade coffee in Oaxaca, Mexico- Key research findings. Discussion paper 05-39, Resources for the Future, Washington, DC.

3. Daviron, B., Ponte, S., 2005. The Coffee Paradox: Global Markets, Commodity Trade and the Elusive Promise Development. Zed Books, 
London and New York.

4. De Graff, J., 1986. The economics of coffee. Economics of crops in developing countries, 1. Pudoc, Wageningen.

5. De Souza Filho, H.M., Cyphers, D. and Phipps, T., 1993. Factors affecting the adoptions of sustainable agricultural practices. Agricultural and Resources Economics Review, 22, 159-165.

6. Edson, M., Michael, W., Emmanuel, S., and Scott, L., 2003. Changes in Allocation of Land, Production and Farm Size in the Rwandan Smallholder Sector, Rwanda Food Security Research Project/ MINAGRI.

7. Ellis, F. (1998). Household strategies and rural livelihood diversification. Journal of Development Studies, 35(1), 1-38.

8. Gonzalez, D. (2001). A Coffee crisi's devasting domino effect in Nicaragua. The New York Times (August 29), A3.

9. Giovannucci, D., 2001. Sustainable Coffee Survey of the North American Speciality Coffee Industry. Speciality Coffee Association of America, Long Beach, CA.

10. Goivannuci, D., Reardon, T., 2000. Understanding grades and standards and how to apply them. In: The Guide to Developing Agricultural Markets and Agro-enterprises.

11. Hakelius, K., 1996. Cooperative values: farmers' cooperatives in the minds of the farmers. Swidish University of Agricultural Sciences, Uppsala.

12. Hazell, P., 2000. Could futures markets help growers better manage coffee price risks in Costa Rica? Discussion Paper, No 57. IFPRI, Washington, DC.

13. Karol, B., 2006, State Power, Entrepreneurship, and Coffee: The Rwandan Experience. Working Paper, Enterprise Africa.

14. Lewin, B., Giovannucci, D. and Varangis, P., 2004. Coffee Markets New paradigms in global supply chain and demand. Agriculture and Rural Development Discussion Paper 3, The World Bank, Washington, DC.

15. National Institute of Statistics of Rwanda (2008). Quarterly Economic Review/January to march 2008.

16. OCIR Café, Rapports Annuels (2002, 2003, 2003, 2004, 2005, 2006, 2007), Kigali-Rwanda.

17. Oxfam (Brown, O., Charavat, C., \& Eagleton, D.) (2001). The Coffee Market: A background study. London: Oxfam.

18. Oxfam (Gresser, C., \& Tickell, S.) (2002). Mugged: Poverty in coffee cup. London: Oxfam International

19. Ponte, S. (2002a). The "Latte Revolution"? Regulation, markets and 
consumption in the global coffee chain. World Development, 30(7), 1099-1122.

20. Ponte, S. (2002b). Brewing a bitter cup? Derugalation, quality and the re-organization of coffee marketing in East Africa. Journal of Agrarian Change, 2(2), 248-272.

21. Scott, L., Jean Baptiste, N., and Emmanuel, S., 2003. Decaffeinated? Situation, Trends, and Prospects for Coffee Production in Rwanda. Rwanda Food Security Research Project/ MINAGRI.

22. Talbot, J.M., 1997. Where does your coffee dollar go? The Division of Income and Surplus Along the Coffee Commodity Chain. Studies in Comparative International Development, 32 (1), 56-91.

23. Xinshed, D., Shenggen, F., Sam, K., and Bingxin Y., 2007. Agricultural Growth and Investment Options for Poverty Reduction in Rwanda. IFPRI Discussion Paper 00689. 